\title{
Thrombolytic Activity of Alkaline Protease Purified from a Mutant Strain Bacillus licheniformis MZK05M9
}

\author{
Md. Asad uz Zaman', Taqiyah Akhtar', A.T. M. Zafrul Azam, Md. Arafat Al Mamun, \\ Md. Mozammel $\mathrm{Hoq}^{3}$ and Md. Abdul Mazid ${ }^{1}$ \\ ${ }^{1}$ Department of Pharmaceutical Chemistry, Faculty of Pharmacy, University of Dhaka, Dhaka-1000, \\ Bangladesh \\ ${ }^{2}$ Centre for Advanced Research in Sciences, University of Dhaka, Dhaka-1000, Bangladesh \\ ${ }^{3}$ Department of Microbiology, University of Dhaka, Dhaka-1000, Bangladesh
}

(Received: November 08, 2017; Accepted: January 14, 2018; Published: January 30, 2018)

\begin{abstract}
Investigations were performed to find out new microbial enzymes as thrombolytics having better efficacy and specificity. Mutant strain of Bacillus species, B. licheniformis MZK05M9 was cultured in modified urea-glucose media followed by purification using ammonium sulphate precipitation and ultrafiltration through centricon tube of specific MWCO value. The production method yielded $823.42 \mathrm{units} / \mathrm{mg}$ of the crude enzyme from mutant strain MZK05M9 and after purification 37695.64 units/mg. The molecular weight of the purified enzyme was estimated as $27.2 \mathrm{kDa}$ and purification increased its specific activity to 16.5 fold with a recovery of $10 \%$. The purified proteases were identified as serine proteases by irreversible inhibition of activity with phenylmethylsulfonyl fluoride (PMSF) and it exhibited 32.84\% thrombolytic activity, by in vitro clot lysis assay. Stability studies showed that crude enzyme from mutant strain MZK05M9 remained stable up to a temperature of $45^{\circ} \mathrm{C}$ and showed maximum stability at $\mathrm{pH}$ range 7.5 to 8.5 . Our observation indicates that proteases produced by Bacillus licheniformis mutant have the potential to be developed as a viable thrombolytic agent.
\end{abstract}

Key words: Bacillus licheniformis, protease, purification, thrombolytic activity.

\section{Introduction}

Accumulation of fibrin in the blood vessels usually results in thrombosis. Various types of thrombosis lead to different cardiovascular diseases (CVD) such as myocardial infarction (commonly known as heart attack), stroke, transient ischemic attack (TIA), venous thromboembolism (VTE) (e.g., deep vein thrombosis (DVT), pulmonary embolism (PE), etc. CVDs are the primary cause of death globally and are projected to remain the single leading cause of death (Mathers and Loncar, 2006).

Thrombolytic agents are used to dissolve a blood clot (thrombus) by activating plasminogen, which forms a cleaved product called plasmin. Plasmin is a proteolytic enzyme that is capable of breaking crosslinks between fibrin molecules, which provide the structural integrity of blood clots. Because of these actions, thrombolytic drugs are also called "plasminogen activators", "fibrinolytic drugs", "clotdissolving medication" and "clot buster" etc. The available thrombolytic agents are of two types, based on their different working mechanisms. One is plasminogen activator, such as tissue-type plasminogen activator (t-PA) (Collen and Lijnen, 2004), urokinase (Duffy 2002), bacterial streptokinase (s-PA), which activate plasminogen into active plasmin to degrade fibrin. Recombinant forms of normal human plasminogen activators t-PA and $\mathrm{u}$-PA are used in clinical intervention. The other type is plasmin-like proteins, which directly degrade the fibrin in blood clots, thereby dissolving the thrombus rapidly and completely. Lumbrokinase from earthworm and fibrolase from snake venom are well-known plasmin-like proteins (Mihara et al., 1991; Chen et al., 1991).

Correspondence to: Md. Abdul Mazid, E-mail: ma.mazid@du.ac.bd 
Although t-PA and urokinase are still widely used in thrombolytic therapy today, their expensive prices and undesirable side effects, such as risk for internal hemorrhage within the intestinal tract, their uses are often limited and investigations are being pursued to search for cheaper and safer resources. The microbial sourced streptokinase is the least expensive, but immunogenic as it is a non-human protein (Lee, 1995; Jennings, 1996). This immunogenicity restricts multiple treatments with streptokinase (Collen et al., 1992; Bick, 1982). Microbial fibrinolytic enzymes have attracted much more medical interest in recent decades (Tough, 2005, Goldhaber and Bounameaux, 2001). Recently, protease produced by Bacillus species have been identified to possess thrombolytic activity such as nattokinase (NK) from Bacillus natto and subtilisin DFE and subtilisin DJ-4 from Bacillus amyloliquefaciens (Sumi et al., 1987; Kim and Choi, 2000; Peng et al., 2003). These proteases are mainly serine (e.g., Nattokinase) or metalloproteases (e.g., Armillaria mellea metallo protease) or mixture of both serine and metallo protease (e.g., Protease from Streptomyces) (Liu et al., 2005; Wang et al., 1999). In 1987, B. natto producing NK was first screened from a traditional Japanese soybean-fermented food named natto. Subsequently, some other Bacilli such as B. Amyloliquefaciens DC-4 (Peng et al., 2003), Bacillus sp. CK (Kim et al., 1996), Bacillus sp. strains DJ-2 and DJ-4 (Kim and Choi 2000; Choi et al., 2005), and Bacillus sp. KA38 (Kim et al., 1997) from different fermented foods were discovered to produce fibrinolytic enzymes. These exciting findings imply the possibility of consuming fermented foods to prevent cardiovascular diseases (Suzuki et al. 2003). These findings have opened a gateway to isolate newer thrombolytic agents from Bacillus species as future antithrombotic therapy. The present study has been designed to produce and purify the proteases produced by Bacillus species obtained from different sources such as foods, soils, etc to be developed as thrombolytics agent to prevent or cure thrombosis and other related diseases.

\section{Materials and Methods}

Microorganism and culture: The microorganism used was a mutated Bacillus species, Bacillus licheniformis MZK05M9 isolated from feather decomposed soil (Hoq et al., 2005). Stock culture of the organism was maintained at $-70^{\circ} \mathrm{C}$ in nutrient broth containing $10 \%$ glycerol. A loopful of the spore suspension from the lyophilized seed-lot of mutant $B$. licheniformis MZK05M9 was streaked onto TSA plates and incubated for 2 days at $37^{\circ} \mathrm{C}$. One loopful of the organisms from these plates were transferred to screw cap test tubes containing $5 \mathrm{ml}$ sterile TSB and incubated overnight at $37^{\circ} \mathrm{C}$. These were used as inocula for fermentation in Erlenmeyer flasks.

The seed culture $(5 \mathrm{ml}$ of mutant $B$. licheniformis MZK05M9 was transferred to $95 \mathrm{ml}$ of modified urea-glucose medium in each $500 \mathrm{ml}$ Erlenmeyer flask. $1000 \mathrm{ml}$ modified urea-glucose medium contained $20 \mathrm{~g}$ glucose, $10 \mathrm{~g}$ urea, $5 \mathrm{~g} \mathrm{~K}_{2} \mathrm{HPO}_{4}, 1 \mathrm{~g}$ $\mathrm{CaCl}_{2}$ and $1 \mathrm{~g} \mathrm{MgSO}_{4}$ (initial $\mathrm{pH}$ 7.5). The inoculated flasks were placed in a thermostated orbital shaker for $48 \mathrm{hrs}$, at $37^{\circ} \mathrm{C}$ and $150 \mathrm{rpm}$.

Purification of enzyme: After $48 \mathrm{~h}$ of fermentation in the modified urea-molasses medium, the extracellular alkaline protease rich fraction was harvested by centrifugation of ferment at $6,000 \mathrm{rpm}$ for $10 \mathrm{~min}$. The culture supernatant obtained after centrifugation was subjected to ammonium sulphate precipitation at a saturation level from $50 \%$ upto $80 \%$ $(\mathrm{w} / \mathrm{v})$ and after centrifugation at $10,000 \mathrm{~g}$ at $4{ }^{\circ} \mathrm{C}$ for 30 minutes the resulting precipitate was dissolved in $50 \mathrm{mM}$ Tris- $\mathrm{HCl}$ buffer ( $\mathrm{pH}$ 7.0) (Dawson et al., 1986; Taylor, 1953). The crude enzyme as well as partially purified enzyme was evaluated for protease activity and thrombolytic activity. Furthermore, partially purified enzyme was concentrated by ultrafiltration through centricon tubes (Maity et al., 2007; Guerrieri et al., 2000). In this purification purpose, $100 \mathrm{kDa} \mathrm{MWCO}$ and $30 \mathrm{kDa}$ MWCO centricon tubes (Amicon ${ }^{\circledR}$, Millipore) were used and proteins were concentrated by centrifugation at 5,000 $\mathrm{g}$ for 15 minutes $(2.5 \times 30 \mathrm{~cm}$, Amersham Biosciences, Sweden). The permeate enzymes were then used for thrombolytic activity study. 
Estimation of extracellular soluble protein and protease activity: The extracellular soluble protein concentration was determined by Bradford method (Bradford, 1976) using bovine serum albumin (BSA) as standard. Absorbances were recorded at $595 \mathrm{~nm}$ using a spectrophotometer (GENESYS ${ }^{\mathrm{TM}} 5$, Thermo Scientific) and protein concentration was determined based on the standard curve.

Enzyme activity was determined using azocasein (Sigma, USA) as a substrate by a modified procedure described by Krieger and Lockwood (Kreger and Lockwood, 1981). Briefly, $400 \mu \mathrm{l}$ of 1\% Azo-casein solution in $0.05 \mathrm{mM}$ Tris-HCI buffer ( $\mathrm{p}$ 8.5) was added to $400 \mu \mathrm{l}$ of culture supernatant and kept for 1 hour at $37^{\circ} \mathrm{C}$ in a shaking water bath. The reaction was stopped by the addition of $135 \mu \mathrm{l}$ of $35 \%$ trichloroacetic acid (TCA) and the mixture was kept at $4{ }^{\circ} \mathrm{C}$ for at least $10 \mathrm{~min}$. After centrifugation at $13,000 \mathrm{rpm}$ for $10 \mathrm{~min}, 0.75 \mathrm{ml}$ of supernatant was mixed with $0.75 \mathrm{ml}$ of $1 \mathrm{M} \mathrm{NaOH}$ and the absorbance was recorded at $440 \mathrm{~nm}$ within one minute in spectrophotometer, (GENESYS ${ }^{\mathrm{TM}}$ 5, Thermo Scientific). The control was prepared by adding TCA before mixing the culture supernatant with azo-casein solution. One unit of protease activity was determined as the amount of enzyme that produces an increase in absorbance of 0.01 at $440 \mathrm{~nm}$ under the above assay condition. The value obtained is expressed in $\mathrm{U} / \mathrm{ml}$

Protein molecular weight determination: To estimate the molecular weight, permeate protein from $100 \mathrm{kDa}$ MWCO and $30 \mathrm{kDa}$ MWCO centricon tube was subjected to sodium dodecyl sulphate polyacrylamide gel electrophoresis (SDS-PAGE) using $12 \%$ gradient polyacrylamide gel and $4 \%$ polyacrylamide stacking gel. The gel sheet was stained with $0.25 \%$ coomassie brilliant blue (CBB) [Laemmli, 1970; Merril, 1990]. The molecular weight of the partially purified enzyme was determined by gel image using Alpha View software.

Stability of enzymes: Thermal stability of crude protease was determined by pre-incubating the protease at temperatures of $25,30,40,50,60$ and $70^{\circ} \mathrm{C}$ for $1 \mathrm{hrs}$. After incubation, the enzyme was assayed by incubating with $1 \%(\mathrm{w} / \mathrm{v})$ azo-casein as substrate at $37{ }^{\circ} \mathrm{C}$ and the protease activity was measured at $440 \mathrm{~nm}$ taking untreated enzyme as control. The control was prepared by adding TCA before mixing the culture supernatant with azo-casein solution. On the other hand, the $\mathrm{pH}$ stability of crude protease was determined by diluting the enzyme in different buffers ( $\mathrm{pH} 5.0-11.0)$ and incubated for 1 $\mathrm{h}$ at room temperature. Following buffers were used for this study: Citric acid buffer ( $\mathrm{pH} 5.0$ - 6.0); phosphate buffer ( $\mathrm{pH} 7.0-8.0)$; carbonate buffer $(\mathrm{pH}$ 9.0 - 10); and sodium bicarbonate buffer ( $\mathrm{pH} 11.0$ ). After incubation, the enzyme activity was assayed as described above.

Thrombolytic activity assay: To assess the thrombolytic activity of enzyme in vitro clot lysis model was adopted (Al-Mamun et al., 2012). Streptokinase was used as standard and PBS was used as control. In this method, fresh venous blood collected from healthy volunteers at the Dhaka University Medical Center following institutional ethical guidelines and transferred in different preweighed sterile microcentrifuge tube $(500 \mu \mathrm{l} /$ tube $)$ and incubated at $37^{\circ} \mathrm{C}$ for 45 minutes. After clot formation, serum was completely removed and each tube having clot was again weighed to determine the clot weight. Each microcentrifuge tube containing clot was properly labeled and $100 \mu \mathrm{l}$ of partially purified enzymes from 100 MWCO centricon tube permeate, commercially available streptokinase (of different dilutions) and PBS was added to the respective tubes. After incubation of all tubes at $37^{\circ} \mathrm{C}$ for 90 minutes, fluid released due to lysis of clot was removed from each tube and weighed again. Difference in weight taken before and after clot disruption was considered to calculate the clot lysis in percentage. The percentage of weight loss in each tube was considered as an evidence of thrombolytic activity of partially purified enzyme by comparing with streptokinase and control. The assay was repeated thrice and the values were calculated as mean \pm SEM. The significance between $\%$ clot lysis by streptokinase and purified protease was tested by the paired $t$-test analysis. 


\section{Results and Discussion}

The supernatant from the culture media of strain MZK05M9 was subjected to fractional ammonium sulphate precipitation, where the crude enzymes precipitated at $60 \%$ of ammonium sulphate saturation. The initial total protein content was $264.286 \mathrm{mg}$ which reduced to $28.696 \mathrm{mg}$ after salting out. Ultrafiltration with $100 \mathrm{kDa}$ MWCO centricon tube reduces the protein concentration to 0.589 $\mathrm{mg} / \mathrm{ml}$. The initial specific activity of crude enzyme was $849.811 \mathrm{mg} / \mathrm{ml}$ and after successive purification through salt precipitation and ultrafiltration, the final specific activity increased to 2286.863 units/mg and
37707.028 units $/ \mathrm{mg}$, respectively (Table 1). The total protein content in crude enzymes was decreased due to ammonium sulphate precipitation. However, purification process yielded 16.5 folds increase in specific activity with a recovery of $10 \%$. The partially purified enzyme obtained by ultrafiltration through centricon tube could retain the specific molecular weight proteins. This suggests that our approaches for purification were effective. Furthermore, irreversible inhibition of enzyme activity with phenylmethylsulfonyl fluoride (PMSF) confirmed that purified enzyme was serine protease.

Table 1. Purification of thrombolytic protease from mutant Strain B. licheniformis MZK05M9.

\begin{tabular}{lccccc}
\hline Purification step & $\begin{array}{c}\text { Total activity } \\
(\mathrm{U})\end{array}$ & $\begin{array}{c}\text { Total protein } \\
(\mathrm{mg})\end{array}$ & $\begin{array}{c}\text { Specific activity } \\
(\mathrm{U} / \mathrm{mg})\end{array}$ & $\begin{array}{c}\text { Purification } \\
\text { fold }\end{array}$ & $\begin{array}{c}\text { Recovery } \\
(\%)\end{array}$ \\
\hline Crude enzyme & 222030 & 264.286 & 849.811 & 1 & 100 \\
Ammonium sulfate precipitated enzyme & 65629.8 & 28.696 & 2286.863 & 2.777 & 29.559 \\
100 kd Centricon tube permeate & 22213.5 & 0.589 & 37707.028 & 16.482 & 10.004 \\
\hline
\end{tabular}

Table 2. Thrombolytic enzymes from Bacillus species.

\begin{tabular}{|c|c|c|c|c|c|}
\hline Author & Microorganism & $\begin{array}{c}\text { Specific } \\
\text { activity }(\mathrm{U} / \mathrm{mg})\end{array}$ & $\begin{array}{l}\text { Purification } \\
\text { Fold } \\
\end{array}$ & $\begin{array}{c}\text { Recovery } \\
(\%)\end{array}$ & $\begin{array}{l}\text { M.W. } \\
\text { (kDa) }\end{array}$ \\
\hline Kim et al. 1996 & Bacillus sp. CK 11-4 & 143.3 & 7.5 & 95 & 28.2 \\
\hline Lee et al. 2010 & B. amyloliquefaciens $\mathrm{CH} 86-1$ & 100.2 & 25.96 & 1.22 & 27 \\
\hline Cheng et al. 2006 & B. subtilis DC33 & $15,494.90$ & 34.6 & 13 & 30 \\
\hline Yin et al. 2010 & B. subtilis YJ1 & 1791.9 & 9.2 & 9.5 & 27.7 \\
\hline Chang et al. 2000 & B. subtilis IMR-NK1 & 4400 & 9.2 & 6.5 & 31.5 \\
\hline Park et al. 2013 & B. subtilis WRL101 & 112.2 & 8.6 & 39.7 & 29 \\
\hline Zhang et al. 2005 & Subtilisin DFE in E. coli & 4597 & 5.4 & 5.2 & \\
\hline Jeong et al.2001 & B. subtilis $\mathrm{BK}-17$ & 63165 & 929 & 29 & 31 \\
\hline Balaraman et al.2006 & B. sphaericus & 4258 & 91 & 25 & 18.6 \\
\hline Kotb et al.2011 & B. subtilis $\mathrm{K} 42$ & 19025.9 & 389.6 & 14 & 20.5 \\
\hline Sanusi et al. 2012 & Bacillus sp. strain B1 & 1.17 & 59 & 0.51 & 45 \\
\hline Jo et al. 2011 & B. amyloliquefaciens MJ5-41 & 11.58 & 3.99 & 33.81 & 27 \\
\hline Hwang et al. 2007 & B.licheniformis KJ-31 & 242.8 & 19.0 & 0.2 & 37 \\
\hline Asad uz Zaman et al. 2016 & B. licheniformis EMS250-O-1 & 40180.46 & 12.28 & 17.79 & 25.5 \\
\hline
\end{tabular}

For SDS-PAGE analysis of purified protein, protein sample was taken from $100 \mathrm{kDa} \mathrm{MWCO}$ centricon tube retained enzyme, $100 \mathrm{kDa} \mathrm{MWCO}$ centricon tube permeate enzyme and $30 \mathrm{kDa} \mathrm{MWCO}$ centricon tube permeate enzyme. Gel imaging analysis by Alpha View software predicted the 
presence of approximately $27.2 \mathrm{kDa}$ protein band present in both protein sample taken from strain MZK05M9 (Figure 1). The purified enzymes were tested for its thrombolytic activity followed by the method (Al-Mamun et al., 2012) described earlier.

The temperature stability of the protease from strain MZK05M9 showed that the activity of Bacillus sp. MZK0509 remained more or less stable up to a temperature treatment of $45^{\circ} \mathrm{C}$, after which the activity began to decrease slowly and after $55^{\circ} \mathrm{C}$, it dropped rapidly reaching the lowest value of 14.7 $\mathrm{U} / \mathrm{ml}$ at $70^{\circ} \mathrm{C}$ (Figure 2). The highest enzyme activity was obtained at the lowest temperature treatment of $25^{\circ} \mathrm{C}$ and the value recorded was $519.8 \mathrm{U} / \mathrm{ml}$. The organism, MZK05M9 showed highest enzyme activity and stability at the $\mathrm{pH}$ range between 7.5 to 8.5 and there is decrease in activity or stability with decreasing or increasing $\mathrm{pH}$ from that point. The highest activity obtained at the point of highest stability was $532 \mathrm{U} / \mathrm{ml}$ (Figure 2).

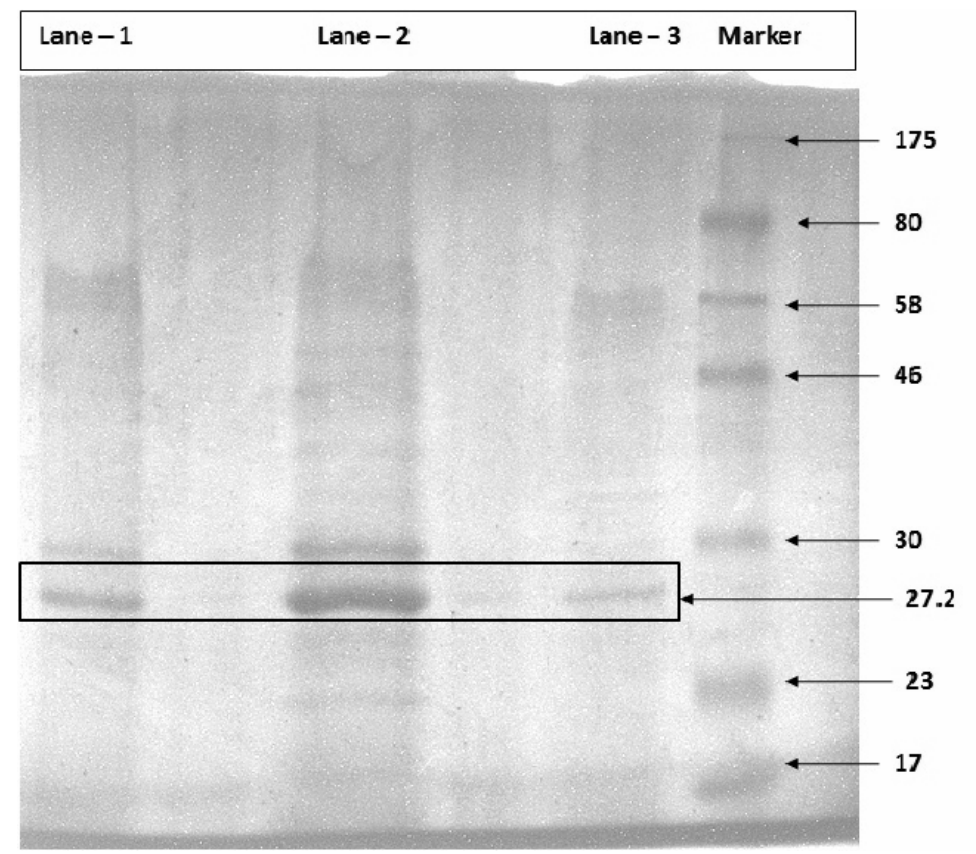

Figure 1. Molecular weight of the purified protease from Bacillus sp. MZK05M9. Lane 1: $100 \mathrm{kDa}$ MWCO Centricon tube retained enzyme, Lane 2: $100 \mathrm{kDa}$ Centricon tube permeate enzyme, Lane 3: $30 \mathrm{kDd}$ MWCO Centricon tube permeate enzyme.
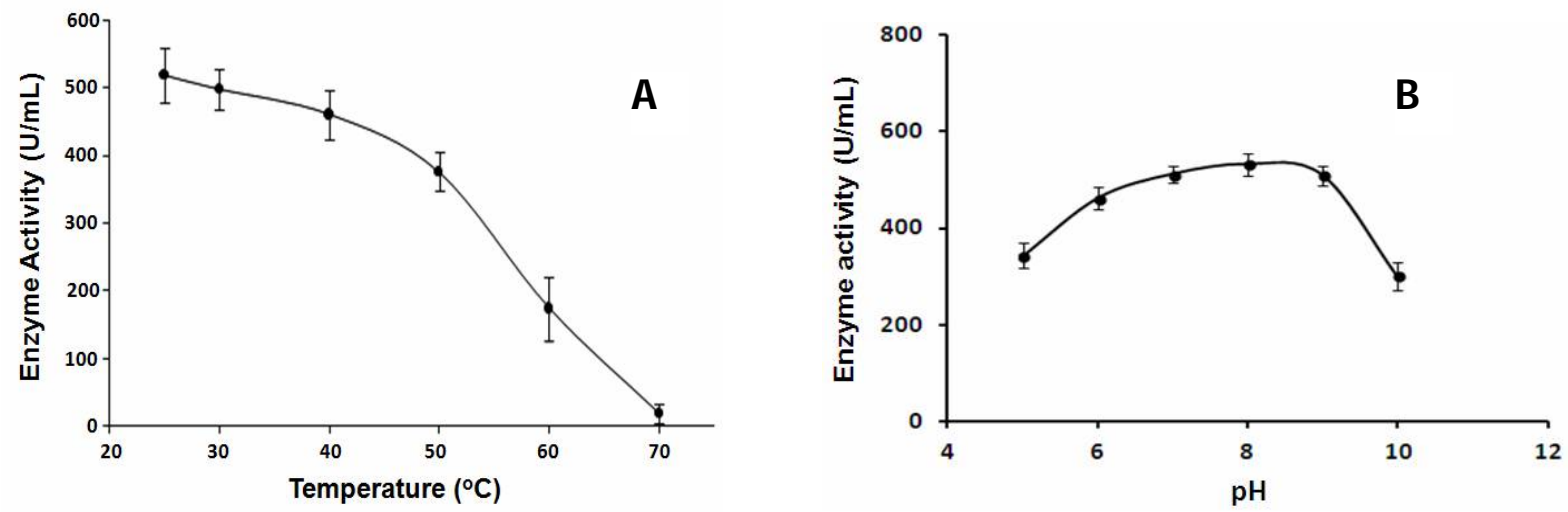

Figure 2. Effect of temperature (A) and $\mathrm{pH}(\mathrm{B})$ on the stability of crude alkaline protease 


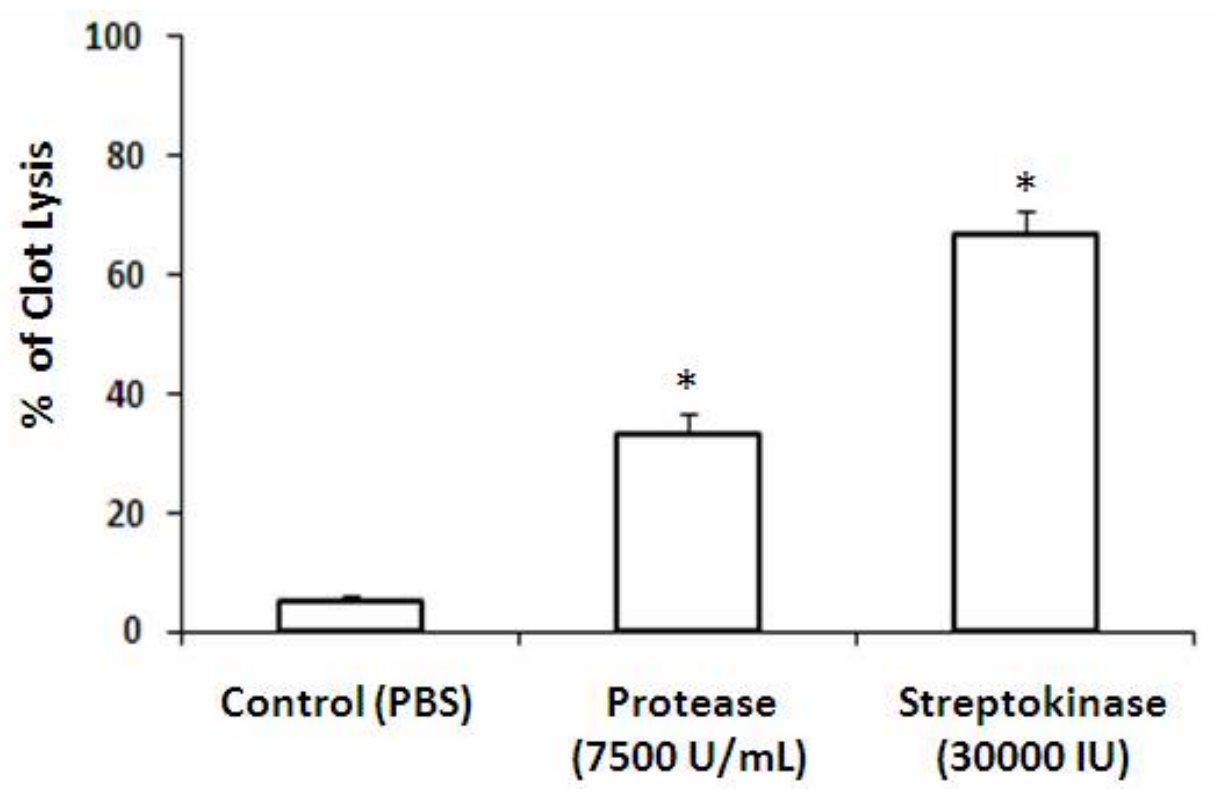

Figure 3. Thrombolytic effects of purified protease from Bacillus sp. MZK05M9. with streptokinase and PBS. Data represented as mean \pm SEM of three independent experiments. $* \mathrm{P}<0.001$ vs control (phosphate buffered saline).

To evaluate the thrombolytic activity of the purified enzyme, blood was withdrawn from three healthy volunteers following ethical guidelines set up by Ethical Review Committee of Faculty of Pharmacy, University of Dhaka. Collected blood was allowed to form clots and used for the assay as described under materials and methods. Thrombolytic activity assay data showed that the average $\%$ of clot lysis by the enzyme obtained from Bacillus sp. MZK05M9 were $28.36 \pm 2.16 \%, 38.21 \pm$ $1.96 \%$ and $31.81 \pm 2.09 \%$, respectively for three independent assays carried out in triplicate (Figure 3) with an average activity of $32.79 \%$. The difference in thrombolytic action between the volunteers in response to average activity might be due to body physiological difference (age, weight, \% of clotting factor, food habit, etc.). Previous work on purification and characterization of thrombolytic enzymes from bacterial sources reported that the purified thrombolytic enzyme has a molecular weight within the range of $20-45 \mathrm{kDa}$ (Table 2). This is an indication of thrombolytic activity of the purified protein.

\section{Conclusion}

Thrombolytic enzymes, including plasminogen activators have been reported from various microbes. However, except for streptokinase (a bacterial protein from beta haemolytic E. coli), none of them are practically in use as a thrombolytic agent. Although, the beneficial effects of thrombolytic therapy are now well established and the biochemical mechanisms of thrombolytic therapy have been elucidated, but the search for alternative and complimentary therapy is still continuing due to some reasons including availability and diversity of natural resources, easy access and affordability. The nature of thrombolytic activity of the protease on blood clot was similar to that of streptokinase. From the above study, we can conclude that, the thrombolytic proteases obtained from $B$. licheniformis strain MZK05M9 has the potential to be developed as novel and economic therapeutic agents for the treatment of thrombolytic and related diseases with fewer side effects in future.

\section{Acknowledgement}

Authors gratefully acknowledge the Ministry of Science and Technology, Government of the People's Republic of Bangladesh for funding support under 
special allocation for Science and Technology Programme’ 2015-2016 (S1.217, Gr.S1.91,MEDI;S).

\section{References}

Al-Mamun, M.R., Amrin, N., Begum, J. and Mazid, M.A. 2012. Thrombolytic activity of some spices and plants available in Bangladesh. Thai J. Phar Sci. 36, 72-77.

Asad uz Zaman, M., Al Mamun, M.A., Khan, S.N., Hoq, M.M. and Mazid, M.A. 2016. Partial Purification of Alkaline Protease as Thrombolytic Agent from Mutant Strain Bacillus licheniformis EMS250-O-1. Dhaka Univ. J. Pharm. Sci. 15, 135-141.

Balaraman K. and Prabakaran, G. 2007. Production and purification of a fibrinolytic enzyme (thrombinase) from Bacillus sphaericus. Indian J. Med. Res. 126, 459-464.

Bick, R.C. 1982. Clinical relevance of anti-thrombin-III. Semin Thromb Hemost. 8, 276-287.

Bradford, M.M. 1976. A rapid and sensitive method for the quantitation of microgram quantities of protein utilizing the principle of protein-dye binding. Anal. Biochem. 72, 248-254.

Chang, C.T., Fan, M.H., Kuo, F.C. and Sung, H.Y. 2000. Potent fibrinolytic enzyme from a mutant of Bacillus subtilis IMR-NK1. J. Agric. Food Chem. 48, 32103216.

Chen, H.M., Guan, A.L. and Markland, F.S. 1991. Immunological properties of the fibrinolytic enzyme (fibrolase) from southern copperhead (Agkistrodon contortrix contortrix) venom and its purification by immunoaffinity chromatography. Toxicon 29, 683694.

Choi, N.S., Yoo, K.H., Hahm, J.H., Yoon, K.S., Chang, K.T., Hyun, B.H., Maeng, P.J. and Kim, S.H. 2005. Purification and characterization of a New Peptidase, Bacillopeptidase DJ-2, Having Fibrinolytic Activity: Produced by Bacillus sp. DJ-2 from Doen-Jang. $J$ Microbiol. Biotechnol. 15, 72-79.

Collen, D., DeCock,V., Vanlinthout, I., Declerck, P.J., Lijnen, H.R. and Stassen, J.M. 1992. Comparative thrombolytic and immunogenic properties of staphylokinase and streptokinase. Fibrinolysis 6, 232242.

Collen, D. and Lijnen, H.R. 2004. Tissue-type plasminogen activator: a historical perspective and personal account. J. Throm. Haemost. 2, 541-546.

Dawson, R.M.C., Elliott, D.C., Elliott, W.H. and Jones, K.M. 1986. Data for biochemical research. 3rd ed. Clarendon Press, Oxford, United Kingdom.

Duffy, M.J. 2002 Urokinase plasminogen activator and its inhibitor, PAI-1, as prognostic markers in breast cancer: from pilot to level 1 evidence studies. Clin. Chem. 48, 1194-1197.
Goldhaber, S.Z. and Bounameaux, H. 2001. Thrombolytic therapy in pulmonary embolism. Semin. Vasc. Med. 1, 213-220.

Guerrieri, N., Scippa, S., Maietti, M., de Vincentiis, M. and Cerletti, P. 2000. Protease activity in fractionated blood cells of the vanadium accumulating ascidian Phallusia mammillata. Comp. Biochem. Physiol. A. Mol. Integr. Physiol. 125, 445-450.

Hassanein, W.A., Kotb, E., Awny, NM. and El-Zawahry, Y.A. 2011. Fibrinolysis and anticoagulant potential of a metallo protease produced by Bacillus subtilis K42. J. Biosci. 36, 773-779.

Hwang, K.J., Choi, K.H. Kim, M.J. Park, C.S. and Cha, J. 2007. Purification and characterization of a new fibrinolytic enzyme of Bacillus licheniformis KJ-31, isolated from Korean traditional Jeot-gal. J Microbiol. Biotechnol. 17, 1469-1476.

Hoq, M.M., Siddiquee, K.A.L., Kawasaki, H. and Seki, T. Keratinolytic activity of some newly isolated Bacillus species. J. Biol. Sci. 5, 193-200.

Jennings, K. 1996. Antibodies to streptokinase - once is enough. BMJ 312, 393-394.

Jeong, Y.K., Park, J.U., Baek, H., Park, S.H., Kong, I.S., Kim, D.W. and Joo, W.H. 2001. Purification and biochemical characterization of a fibrinolytic enzyme from Bacillus subtilis BK-17. World J. Microbiol. Biotechnol. 17, 89-92.

Jo, H.D., Lee, H.A., Jeong, SJ. and Kim, J.H. 2011. Purification and characterization of a major fibrinolytic enzyme from Bacillus amyloliquefaciens MJ5-41 isolated from Meju. J Microbiol Biotechnol. 21, 11661173.

Kim, S.H., Choi, N.S. 2000. Purification and characterization of subtilisin DJ-4 secreted by Bacillus sp. strain DJ-4 screened from Doen-Jang. Biosci. Biotechnol. Biochem. 64, 1722-1725.

Kim, H.F., Kim, G.T., Kim, D.K., Choi, W.A., Park, S.H., Jeong, Y.K., Kong, I.S. 1997. Purification and characterization of a novel fibrinolytic enzyme from Bacillus sp. KA38 originated from fermented fish. $J$. Ferment. Bioeng. 84, 307-312.

Kim, W., Choi, K., Kim, Y., Park, H. Choi, J., Lee, Y., Oh, H., Kwon, I. and Lee, S. 1996. Purification and characterization of a fibrinolytic enzyme produced from Bacillus sp. strain CK 11-4 screened from Chungkook-Jang. Appl. Environ. Microbiol. 62, 14882482.

Kreger, A. and Lockwood, D. 1981. Detection of extracellular toxin produced by Vibrio vulnificus. Infect. Immun. 33, 588-590.

Laemmli, U. 1970. Cleavage of structural protein during the assembly of the head of bacteriophage T4. Nature 227, 680-685.

Lee, H.S. 1995. How safe is the re-administration of streptokinase. Drug Safe 13, 76-80. 
Lee, A.R., Kim, G.M., Lee, K.W., Park, J.Y., Jo, H.D., Cha, J., Song, Y.S., Chun, J. and Kim, J.H. 2010. Characterization of a $27 \mathrm{kDa}$ fibrinolytic enzyme from Bacillus amyloliquefaciens CH86-1 isolated from cheonggukjang. J. Kor. Soc. Appl. Biol. Chem. 53: 5661 .

Liu, J.G., Xing, J.M., Chang, T.S., Ma, Z.Y. and Liu, H.Z. 2005. Optimization of nutritional conditions for nattokinase production by Bacillus natto NLSSE using statistical experimental methods. Process Biochem. 40, 2757-2762.

Maity, G., Mandal, S., Chatterjee, A. and Bhattacharyya, D. 2007. Purification and characterization of a low molecular weight multifunctional cytotoxic phospholipase A2 from Russell's viper venom. J. Chromatogr. B. Analyt. Technol. Biomed. Life Sci. 845, 232-243.

Mathers, C.D. and Loncar D. 2006. Projections of global mortality and burden of disease from 2002 to 2030 . PLoS Med. 3, e442.

Merril, C.R. 1990. Gel staining techniques. Methods in Enzymology 182, 477-488.

Mihara, H., Sumi H, Yoneta. T., Mizumoto. H., Ikedo. R., Seiki. M. and Maruyama. M. 1991. A novel fibrinolytic enzyme extracted from the earthworm Lumbricus rubellus. Jpn J. Physiol. 41, 461-472.

Peng, Y., Huang, Q., Zhang, RH. and Zhang, Y.Z. 2003. Purification and characterization of a fibrinolytic enzyme produced by Bacillus amyloliquefaciens DC-4 screened from douchi, a traditional Chinese soybean food. Comp. Biochem. Physiol. B. Biochem. Mol. Biol. 134, 45-52.

Sumi, H., Hamada, H., Tsushima, H., Mihara, H. and Muraki, H. 1987. A novel fibrinolytic enzyme (Nattokinase) in the vegetable cheese Natto; a typical and popular soybean food in the Japanese diet. Experientia 43, 1110-1111.
Suzuki, Y., Kondo, K., Ichise, H., Tsukamoto, Y., Urano, T. and Umemura, K. 2003. Dietary supplementation with fermented soybeans suppresses intimal thickening. Nutrition 19, 261-264.

Taylor, J.F. 1953. The isolation of proteins. In The proteins: Chemistry, biological activity, and methods", part A (eds. H. Neurath and K.C. Bailey), Academic Press, New York, 2-72.

Tough, J. 2005. Thrombolytic therapy in acute myocardial infarction. Nurs Stand. 19, 55-64.

Wang, C.T., Ji, B.P., Li, B., Nout, R., Li, P.L., Ji, H. and Chen, L.F. 2006. Purification and characterization of a fibrinolytic enzyme of Bacillus subtilis DC33, isolated from Chinese traditional Douchi. J. Ind. Microbiol. Biotechnol. 33, 750-758.

Yin, L.J., Lin, H.H. and Jiang, S.T. 2010. Bioproperties of potent nattokinase from Bacillus subtilis YJ. J. Agric. Food. Chem. 58, 5737-5742.

Park, C.S., Kim, D.H., Lee, W.Y., Kang, D.O. Song, J.J. and Choi, N.S. 2013. Identification of fibrinogeninduced nattokinase WRL101 from Bacillus subtilis WRL101 isolated from Doenjang. Afr. J. Microbio. Res. 7, 1983-1992.

Sanusi. N.A. and Jamaluddin, H. 2012. Purification of a fibrinolytic enzyme from Bacillus $\mathrm{Sp}$ isolated from Budu. J. Teknolog. 59, 63-68.

Wang, J., Wang, M. and Wang, Y. 1999. Purification and characterization of a novel fibrinolytic enzyme from Streptomyces spp. Chin. J. Biotechnol. 15, 83-89.

Zhang, R.H., Xiao, L., Peng, Y., Wang, H.Y., Bai, F. and Zhang, Y.Z. 2005. Expression and characteristics of a novel fibrinolytic enzyme (subtilisin DFE) in Escherichia coli. Lett. Appl. Microbiol. 41, 190-195. 